\title{
KONSTRUKSI MITOS DAN KELOKALAN SEBAGAI ALAT EKSKLUSI (Akses Masyarakat Lokal dan Imigran Terhadap SDA di Desa Lempur Kerinci-Jambi) Dara Kartika Rahma*
}

\begin{abstract}
This paper explains how the community of Lempur Village living in the forest area have a high dependence with nature. The position of the community is considered to interfere with the conservation program, that they must accept losing access to the forest area that has become the state property (TNKS). The loss of access to forest resources, pushed them to be more protective with the land that already allocated to them by the local government. Their openness to migrants began to fade and they did not tolerate new migrants who cleared land, reinforced by the ancestors history to reinforce the concept of localization to see who has the right to access land in Lempur Village. Moreover, other form of their resistance is by reconstruct the myths, addressed to immigrants, corporations, and tourists.
\end{abstract}

Keywords: Resistance, local community, myth, exclusion

Intisari: Tulisan ini menjelaskan bagaimana masyarakat Desa Lempur yang tinggal berbatasan dengan hutan sangat menggantungkan hidupnya terhadap alam. Posisi masyarakat desa dianggap mengganggu program konservasi sehingga mereka harus menerima kehilangan akses di area hutan yang sudah menjadi milik negara (TNKS). Dengan hilangnya akses mereka terhadap sumber daya hutan yang kini dijadikan area konservasi, menuntut mereka untuk lebih protektif terhadap sisa lahan yang memang sudah diperuntukan bagi mereka oleh pemerintah daerah. Keterbukaan mereka terhadap pendatang mulai pudar dan tidak lagi dapat mentoleransi pendatang membuka lahan. Diperkuat dengan sejarah nenek moyang mereka untuk mengukuhkan konsep kelokalan guna melihat siapa yang memiliki hak untuk mengakses tanah di Desa Lempur ini. Selain itu bentuk lain dari perlawanan mereka ialah dengan merekonstruksi kembali mitos-mitos yang sangat kuat digaungkan kepada pendatang, baik imigran, perusahaan, maupun wisatawan.

Kata Kunci: Perlawanan, masyarakat lokal, mitos, eksklusi

\section{A. Pendahuluan}

Pada era Soeharto, kebutuhan modal pembangunan merupakan prioritas utama. Pengusahaan hutan tropika dalam beberapa hal telah berhasil menopang pembangunan nasional dalam hal pendapatan devisa negara, penyerapan tenaga kerja, menumbuhkan pembangunan regional dan pembangunan industri hasil hutan. Sumber daya alam (hutan, tambang, air, mineral) masih dipandang dalam konteks economic sense dan belum dipahami sebagai ecological dan sustainable sense. Sejak rezim tata kelola hutan nasional dan

transnasional, wacana konservasi menjadi arena pengeksklusian, kawasan hutan lindung menjadi tanah yang terlarang untuk pertanian rakyat. Penciptaan kawasan lindung bisa disertai dengan penggusuran. Masyarakat berusaha untuk mendapatkan atau mempertahankan akses ke lahan untuk pertanian, bahkan mereka memperjuangkan tanah yang sejak dulu menjadi tempat bermula mereka bermata pencaharian (Hall 2011). Ide konservasi lingkungan telah menjadi isu penting sehingga masyarakat yang berbatasan dengan hutan dijadikan tumbal untuk tidak lagi mengakses tanah pertanian. Pemisahan manusia dan alam dengan dalih konservasi tersebut menciptakan aktor baru, pola-pola baru komoditisasi dan bentuk baru pemerintahan (White dkk 2012). 


\section{B. Kontestasi Tanah Adat dan Negara} Dalam Bentuk Taman Nasional KerinciSeblat (TNKS)

Sejarah kawasan lindung di Asia Tenggara dimulai pada masa kolonial. Ditetapkan oleh pemerintah Belanda pada tahun 1926-1929² di Kerinci. Penetapan ini bertujuan untuk melindungi area hutan yang menjadi daerah tangkapan air. Pemuka adat dan orang tua di desa hingga saat ini masih mengenal baik daerah tangkapan air tersebut. Kehutanan kolonial dan industri telah bergandengan tangan untuk memberikan perlindungan dan konservasi hutan, dan keduanya bekerja sama membentuk kontrol oleh negara terhadap hutan di Indonesia. Dalam hal ini, membentuk Taman Nasional adalah cara negara membangun kontrol atas hutan. Dan untuk beberapa hal, pembuatan Taman Nasional juga merupakan norma global.

Setelah jatuhnya Soeharto pada tahun 1998, gerakan masyarakat adat dan kepengurusan hutan yang dikelola oleh masyarakat adat menguat (Hall 2011,181). Dalam Undang-undang tentang Kehutanan produk Reformasi, diakui dan diatur secara tegas mengenai hutan adat dan masyarakat hukum adat. Hutan adat adalah hutan negara yang berada dalam wilayah masyarakat hukum adat. Pemerintah menetapkan status hutan adat sepanjang menurut kenyataannya masyarakat hukum adat yang bersangkutan masih ada dan diakui keberadaannya.

Keberadaan hutan adat di Desa Lempur Jambi, berada di wilayah APLatau Area Penggunaan Lain, yang berada di luar hutan negara. Menurut pemerintah daerah, Wilayah hutan APL merupakan wewenang mutlak pemerintah daerah. APL merupakan area di luar kawasan hutan yang digunakan sebagai pembangunan di luar bidang kehutanan³.

\footnotetext{
${ }^{2}$ Berdasarkan Beislet Pemerintah No. 44 tanggal 29 Juni 1926 dan No. 27 tertanggal 9 Desember 1929.

${ }^{3}$ http://regional.kompas.com/read/2013/02/o7/ 02361286/7.Juta.Hektar.APL.Tak.Terlindung
}

Hal ini pula yang membuat pemerintah daerah Kerinci, ketika ditanyakan perihal perizinan Hutan Adat di tingkat nasional yang hingga kini masih terus dalam proses, tidak terlalu mengkhawatirkan apakah status Hutan Adat tersebut sah di mata negara atau tidak.

Masyarakat Desa Lempur merupakan masyarakat dampingan $\mathrm{WWF}^{4}$ ketika TNKS (Taman Nasional Kerinci Seblat) hadir dalam wacana pembangunan ketika itu. Menurut sumber masyarakat desa, mereka sudah mengenal praktek dari kegiatan konservasi ketika mereka masih berada dalam jajahan Belanda. Kemudian diperkuat lagi dengan sosialisasi WWF yang ketika itu merekrut penduduk lokal sebagai anggotanya untuk melakukan sosialisasi mengenai pentingnya konservasi hutan. Masyarakat Desa Lempur sempat mengalami perlawanan dalam masa pemerintahan Belanda ketika area hutannya akan dikonversi mernjadi kebun teh yang akan diberi nama Kayu Aro5. Bentuk perlawanan itu dengan menolak perubahan Hutan Adat yang dulu mereka sebut Hutan Hulu Air menjadi kebun teh. Penolakan ini dilakukan karena mereka khawatir akan terjadinya bencana alam, mengingat desa-desa masyarakat berada di dalam lekukan yang dikelilingi bukit-bukit. Sehingga besar kemungkinan jika Hutan Hulu Air kehilangan fungsinya, maka bencana banjir atau longsor akan menimpa masyarakat desa.

Karena penolakan itulah maka Hutan Hulu Air masih tetap asri dan terjaga oleh masyarakat desa, sehingga ketika masuknya program konservasi oleh WWF, Hutan Hulu Air sebesar 58o hektar itu diakui dan disahkan oleh Bupati Kerinci menjadi Hutan

${ }^{4}$ World Wide Fund for Nature.

${ }^{5}$ Pemberian nama Kayu Aro ini digunakan karena rencana pembuatan lahan kebun teh di mulai dari batas pohon Kayu Aro (yang saat ini menjadi hutan adat). Hingga saat ini, pohon itu dijadikan batas sebagai tanda masuknya mereka ke dalam kawasan hutan adat. Saat ini nama Kayu Aro digunakan sebagai nama kebun teh terbesar di Asia Tenggara, yang berada di Kerinci Hulu. 
Adat Lekuk 50 Tumbi, ${ }^{6}$ dengan alasan sejarah bahwa desa tersebut di awali oleh 50 orang Kepala Keluarga dan membentuk Desa Lempur.

Sampai saat ini, masyarakat desa masih terlibat langsung dalam kegiatan konservasi menjaga hutan Adat dan TNKS yang berbatasan langsung dengan desa mereka. Mereka paham bahwa TNKS sebagai paru-paru dunia yang harus mereka jaga, demi kepentingan dunia dan bukan hanya untuk keberlangsungan hidup masyarakat desa. Namun, mereka merasa kontribusinya dalam menjaga TNKS untuk dunia, tidak dihargai dengan diberikannya kompensasi atas kegiatan tersebut.

Keinginan untuk mendapatkan kompensasi tidak serta merta hadir begitu saja, ini di awali dari pengusiran mereka yang sebagian masyarakatnya telah bermata pencaharian di area yang saat ini telah menjadi Taman Nasional. Bentuk-bentuk penolakan atas pembatasan tanah ini yang kemudian menjadikan mereka harus berjuang untuk bertahan hidup demi tetap berlangsungnya kebutuhan hidup mereka. Dengan serangkaian bentuk perjuangan tersebut, terlihat seperti sebuah kesepakatan antara masyarakat desa dan pemerintah daerah. Sekalipun belum menimbulkan konflik baru setelahnya, masyarakat desa tetap melakukan perlawanan dengan cara mereka yang tidak terorganisir. Sama seperti yang dilakukanoleh Scott di salah sebuah desa di Malaysia, detail-detail pertarungan antara kelas sosial memerlukan unsur fitnah, pergunjingan dan gosip yang bertujuan merusak nama baik, julukan kasar yang sebagian besar hanya bermain di balik layar kehidupan di kampung (2000,xxv). Karena bagaimanapun, ketika negara hadir dan mengambil paksa tanah atas nama negara, masyarakatyang hak-haknya tercerabut secara paksa di atasnya, harus menerima karena mereka adalah Rakyat Indonesia yamg dituntut

${ }^{6}$ Hutan Adat yang awalnya mengelilingi so orang Kepala Keluarga desa, sehingga sekarang menjadi desa Lempur yang berpenduduk banyak. untuk patuh pada hukum negara.

Meminjam istilah hegemoni yang dipakai Gramsci, sebagai suatu cara untuk menyampaikan bagaimana kekuasaan dihayati pada tempat dan waktu tertentu, yang menurutnya selalu merupakan campuran antara pemaksaan dan persetujuan. Gramsci menengarai bahwa persetujuan berkaitan dengan kesadaran. Foucault menengarai bahwa manusia dibentuk oleh praktik kepengaturan yang mungkin tidak mereka sadari, yang berlangsung tanpa persetujuan ataupun penolakan mereka. kekuasaan bisa memberdayakan, sekaligus membatasi dan memaksa. Kekuasaan bekerja melalui praktik-praktik yang sebagian besarnya bersifat rutin dan keseharian (Li 2012, 47-48).

Eksklusi teritorial pada masyarakat yang kawasannya menjadi kawasan konservasi seperti Taman Nasional, secara tegas menjauhkan mereka dari alam, dan hal tersebut tidak lepas dari berbagai bentuk resistensi yang salah satunya ialah memperjuangkan kompensasi atas kehilangan lahan pertanian yang sudah dikelola sejak turun temurun. Kehadiran Taman Nasional Kerinci Seblat (TNKS) yang telah dikukuhkan pada tahun 19927 ${ }^{7}$, membawa bentuk perlawanan di daerah dataran tinggi Kerinci-Jambi. Dalam perlawanan tersebut ternyata membuat pemerintah daerah mengukuhkan dua Hutan Adat pada tahun $2004^{8}$, di Desa Lempur dan Desa Keluru. Hutan adat tersebut merupakan daerah penyangga hutan konservasi, yang bersandarkan dengan UU No. 5 Tahun 19909. Daerah penyangga yang kemudian menjadi hutan adat ini merupakan

7 Surat Pernyataan Menteri Pertanian No. 736/ Mentan/X/1982 tertanggal 14 Oktober 1992

${ }^{8}$ Keputusan Bupati No. 176 Tahun 1992 tentang Pengembangan dan Pembangunan hutan adat desa untuk pengelolaan daerah (desa) Penyangga Taman Nasional Kerinci Seblat.

${ }_{9}$ Mengenai konservasi sumber daya alam hayati dan ekosistemnya menyebutkan bahwa pemerintah dapat menetapkan daerah yang berbatasan dengan kawasan konservasi untuk ditujukan sebagai daerah penyangga. Hal ini bahwa daerah penyangga harus 
kerja sama WWF dan pemerintah daerah guna melegalkan kepemilikan hutan komunal yang mereka kelola di mata hukum dan negara.

Bentuk perlawanan masyarakat terhadap pengusiran, memiliki bentuk yang tidak sama di setiap daerah. Di satu sisi mereka adalah korban rezim kekuasaan, di sisi lain mereka harus berjuang untuk bertahan hidup. Efek dari pengusiran masyarakat dari dalam Taman Nasional Kerinci Seblat membuat mereka lebih ketat dalam menggunakan dan memanfaatkan Hutan Adat hasil dari yang telah mereka perjuangkan. Hutan Adat tersebut menjadi tanah komunal yang dilegitimasi dengan bentuk-bentuk pengakuan dalam hukum adat. Mereka menjaga kepemilikan tanah adat yang mereka miliki dari siapapun yang mencoba untuk mengaksesnya.

"Exclusion as a "good" or "bad" thing are likely to go astray as guides for making land access in the region more just, since exclusion itself is an unavoidable fact of land access and use." (Hall 1971,198)

Mereka yang inklusif di dalam pertanian dan perladangan di desanya, akan mengeksklusi orang lain dari tanah tersebut. Baik itu tetangga, penduduk desa lain, ataupun imigran.

Penduduk yang tereksklusi dari akses atas tanahnya, adalah proses "exclusion" yang terkait dengan konsep akses. Akses diartikan sebagai kemampuan untuk memperoleh manfaat dari sesuatu (the ability to derive benef it from things). Akses dalam pengertian ini mengandung makna "sekumpulan kekuasaan" (a bundle of powers). Dalam pengertian akses semacam ini maka kekuasan diartikan sebagai sesuatu yang terdiri atas elemen-elemen material, budaya dan ekonomipolitik yang terhimpun sedemikian rupa membentuk "bundel kekuasaan" (bundle of powers) dan

berada di luar kawasan, baik sebagai kawasan hutan lain, tanah negara bebas maupun tanah yang dibebani hak yang diperlukan dan mampu menjaga keutuhan kawasan Suaka Alam dan Kawasan pelestarian alam. "jaringan kekuasaan" (web of powers) yang kemudian menjadi penentu akses ke sumber daya (Ribot dan Peluso 2003). Cara melihat akses atas tanah yang beralih dari cara pandang hak (right) menuju kekuasaan (power) dapat menjelaskan proses perolehan tanah (Luthfi, 2013: 197).

\section{Aparat Desa dan Polisi Hutan Sebagai Kaki Tangan Negara}

Ada empat kekuasaan yang mendorong terjadinya eksklusi. Empat hal tersebut ialah Regulation, Force, Market, and Legitimation. Keempat kekuasaan ini menjadi kekuatan besar dalam hal terjadinya eksklusi atau menghilangkan hak orang lain atas area yang telah dikuasai dan diatur oleh pemerintah (Derek Hall, dkk 2011). Pada kasus di Desa Lempur, terdapat dua bentuk kekuasaan yang berpengaruh terhadap hilangnya akses tanah masyarakat di dalam hutan.

1. Kekuasaan dalam bentuk kebijakan negara atau regulation pada umumnya di atur oleh negara. Seperti yang telah saya ulas sebelumnya, ketika masa orde baru, pengeksploitasian sumber daya alam terjadi besar-besaran demi pembangunan negara dan kemakmuran rakyat Indonesia. Namun, kebijakan negara yang di aturdalam UU, melahirkan sebuah hukum yang tidak lepas dari bentuk kekerasan. Tanah kemudian menjadi sumber daya yang diperebutkan karena manusia hidup membutuhkan tanah untuk bermata pencaharian. Masyarakat yang telah lama bermata pencaharian di area hutan, dengan masuknya UU Agraria, mereka dikeluarkan secara paksa, bahkan dikriminalisasikan. Mereka yang bersikeras bermata pencaharian dianggap penebang liar, di penjara, bahkan di tembak. Dalam hal ini ketika TNKS dijadikan dalam UU sebagai wilayah hutan negara yang tidak boleh dimasuki atau dieksploitasi oleh manusia, secara paksa telah mengeksklusi masyarakat desa yang telah membuka lahan pertanian di dalamnya. Mere- 
ka mempertahankan tanah tersebut sebagai hutan adat, sebagai tanah waris nenek moyang mereka terdahulu. Walau begitu tidak lantas membuat mereka dapat masuk dan membuka lahan kembali di dalam hutan TNKS. Hal tersebut kemudian mendorong pemerintah daerah untuk memberikan peluang masyarakat desa membuat patok sebagai batas hutan adat mereka, dengan syarat masyarakat tidak boleh mengekspansi batas tanahnya. Melanggar aturan negara maka akan dikenakan hukum negara, karena itu di dalam Desa Lempur muncul kantor aparat dengan dalih perlindungan masyarakat. Sedangkan masyarakat desa sendiri memiliki hukum adat yang mulai dihidupkan kembali untuk membentuk keteraturan di dalam desa.

2. Kekerasan (force) itu sendiri menjadi salah satu bentuk kekuasaan karena tidak bisa lepas dari kebijakan yang erat dengan penguasa, dalam konteks ini adalah pemerintah. Kekuatan ini identik dengan bentuk kekerasan, karena kekuasaan tanpa kekerasan tidak dapat membentuk keteraturan. Di setiap desa, selalu ada kantor militer, yang tugasnya berfungsi untuk menjaga keamanan desa dari bentuk pelanggaran aturan. Mereka mengatakan jika hukum adat tidak dapat menanggulangi permasalahan di dalam desa, atau terjadi penebangan liar oleh masyarakat pendatang dan mereka tidak mau dikenai hukum adat, maka pihak berwajib yang akan menindak lanjuti hal tersebut. Dengan adanya TNKS, penjagaan semakin diperketat dengan munculnya polisi hutan. Polisi hutan sendiri adalah anggota masyarakat Kerinci yang paham betul karakteristik masyarakatnya. Mereka berpatroli untuk mencari penebang liar yang masuk ke dalam hutan TNKS. Karena polisi hutan adalah kaki tangan negara, masyarakat desa merasa kehadiran polisi hutan menjadi ancaman sekalipun mereka berasal dari lingkungan yang sama. Karena itu Force juga termasuk bentuk kekuasaan yang berada dalam kebijakan negara maupun daerah. Seperti yang kita ketahui, pada jaman orde baru, militer seringkali memburu warga lokal. Warga yang dianggap tidak mau mengikuti aturan negara, dan bentuk dari kekerasan tersebut merupakan bentuk dari pengabdian mereka kepada negara. Dengan adanya tentara di desa-desa, ada dua kekuatan hukum yang secara tidak langsung mengontrol masyarakat dari perbuatan yang melanggar aturan hukum adat dan negara.

Bentuk kekuasaan di atas mampu mengeksklusi masyarakat dari SDA yang sejatinya seluruh umat manusia berhak hidup di atasnya. Masyarakat Kerinci yang masih dalam proses pembangunan harus menerima eksploitasi alamnya yang digunakan negara untuk sebuah tujuan pembangunan. Bentuk dari pengeksklusian penduduk masyarakat dari akses tanahnya, menimbulkan pergeseran di tingkat desa, baik dari aturan adat, respon terhadap mitos, dan dalam menghadapi pendatang maupun imigran.

\section{Resistensi Terhadap PT. Pertamina Geothermal Energy (PGE) Sebagai Counter Exclusion}

Kejadian bencana longsor pada tanggal 26 Januari $2013^{10}$, telah memakan lima orang korban dari PT. Pertamina Geothermal yang ketika itu sedang melangsungkan proyek pengeboran panas bumi di Desa Lempur yang berada di area kebun rakyat, dipercaya oleh masyarakat sebagai bentuk dari kemarahan dewi dan para roh leluhur karena perusahaan tersebut merusak alam mereka. Mereka dianggap mempunyai niat buruk kepada masyarakat desa, dengan cara membodoh-bodohi warga. Dilibatkannya pemuda desa di dalam perusahaan tersebut dianggap telah melecehkan masyarakat,

\footnotetext{
ro http://jambi.tribunnews.com/2013/02/13/
} longsor-geothermal-di-kerinci-murni-bencana-alam. 
karena perusahaan hanya memanfaatkan pemuda desa sebagai satpam, supir, cleaning service, dan sebagai juru masak. Sehingga, ketika bencana longsor itu menimpa camp mereka yang kala itu sedang makan malam bersama pekerja yang merupakan penduduk lokal, dan memakan lima orang korban yang kelimanya merupakan pendatang dari luar, dikaitkan dengan bantuan roh leluhur yang menolong penduduk lokal yang kala itu berada di camp yang sama.

Ketika kejadian itu berlangsung, tidak ada satupun warga desa yang mau membantu mencari korban di reruntuhan, ataupun membawa mereka ke puskesmas terdekat. Ini menjadi satu bentuk perlawanan masyarakat yang merasa kecewa atas kedatangan PGE yang dianggap tidak berlaku baik kepada masyarakat desa. Masyarakat desa menuntut PGE untuk setidaknya memberikan asuransi jiwa kepada masyarakat apabila terjadi bencana yang lebih besar seperti kebocoran panas bumi akibat PGE yang dianggap telah merusak alam. Tindakan arogan yang dilakukan PGE dan pemerintah dengan menyingkirkan masyarakat dari lahan pertaniannya, lalu mengekpsloitasi sumber daya alam tanpa memikirkan dampak alam yang akan terjadi pada masyarakat desa disebut Anderson sebagai gergasi" ${ }^{1}$. Kematian lima orang yang merupakan pendatang tersebut, digaungkan kembali oleh masyarakat desa hingga Kerinci tengah dan Kerinci hulu. Bahwa pendatang harus lebih berhati-hati, mengikuti aturan adat dan tidak bertindak gegabah dalam berinteraksi dengan

"Gergasi penamaan yang diberikan Anderson bagi kawanan rakus pemerintahan terdahulu yang rezimnya tidak memikirkan nasib masyarakat kecil, Soeharto dan kroni-kroninya bermaksud menguasai sumberdaya dengan mengeruk untung. Cara mereka brutal. Selain menempatkan militer dan polisi melawan penduduk, mereka memanfaatkan milisi, pengaman swakarsa, dan preman untuk mendukung kepentingan partai politik, perusahaan swasta, Badan Usaha Milik Negara (BUMN), juga pejabat yang merampas lahan dengan dalih pembangunan. ( $\mathrm{Li}, 2012$ : 102). hutan yang dianggap sakti.

\section{E. Konstruksi Mitos dan Kepribumiannya}

\section{Komodifikasi Alam}

Dilain sisi, masyarakat desa yang sebenarnya telah ter-eksklusi oleh perusahaan dan TNKS ini memanfaatkan idealisasi adat untuk kepentingan perekonomian mereka. Idealisasi adat bisa digunakan untuk berbagai macam kepentingan. Seperti mengecam agenda konservasi, sekaligus agenda eksploitasi. Wacana adat juga dapat digunakan sebagai cara untuk menantang kebijakan pemerintah dan menjadi sumber daya untuk menuntut otonomi politikyang lebih luas. Di saatyang bersamaan, wacana adat bisa menuntut perlindungan pemerintah sekaligus memprotes kebijakannya (Darmanto 2012, 271).

Mereka menjadikan sumber daya alam Danau Kaca yang berada di dalam TNKS sebagai lokasi wisata. Kelompok pemuda pecinta alam PENCAGURA(PecintaAlam Gunung Raya) tersebut meminta dinas kehutanan dan perkebunan mengekspansi hak ulayat mereka hingga Danau Kaca yang berada di area TNKS tersebut, untuk mereka kelola sebagai tempat wisata. Permintaan tersebut kemudian disetujui oleh dinas kehutanan Kerinci. Inisiatif tersebut dianggap pemerintah daerah sebagai bentuk kesiapan masyarakat untuk diberdayakan. Selain hutan TNKS dapat tetap terjaga oleh masyarakat setempat, masyarakat juga dapat mengambil keuntungan dengan membuat lokasi taman nasional sebagai tempat wisata.

Pemberdayaan masyarakat disini untuk meningkatkan harkat dan martabat lapisan masyarakat yang tidak mampu melepaskan diri dari perangkap kemiskinan dan keterbelakangan. Dengan kata lain pemberdayaan adalah suatu upaya meningkatkan kemampuan dan kemandirian masyarakat. Keberhasilan pemberdayaan harus didukung oleh keberdayaan masyarakat melalui peningkatan kemampuan individu untuk mengembangkan kemampuan diri dalam meniti kehidupan bermasyarakat 
(Marzali 2005, 148)

Dengan adanya tempat wisata Danau Kaca, banyak pendatang yang ingin berkunjung ke danau tersebut dengan syarat harus di temani oleh penduduk lokal yang tidak lain adalah kelompok PENCAGURA. Kelompok PENCAGURA yang diberdayakan oleh Dinas Kehutanan dan Perkebunan untuk mengontrol hutan adat dan Taman Nasional dari penebangan liar, membuat masyarakat seolah-olah terinklusi di dalam TNKS karena mereka dilibatkan langsung dalam menjaga area hutan yang telah memberikan kehidupan bagi mereka. Ketika itu mereka tercatat beberapa kali menangkap penebang liar, baik ia adalah penduduk Desa Lempur sendiri yang akhirnya dikenai sanksi adat, maupun pendatang dari luaryang diserahkan kepada pihak berwenang jika menolak untuk membayar ganti rugi kepada desa.

Pendatang yang menginginkan berwisata alam ke Danau Kaca harus ditemani oleh penduduk lokal, karena seringkali pendatang yang masuk ke dalam hutan adat tanpa ditemani penduduk lokal disesat rimba ${ }^{12}$. Biasanya itu terjadi karena mereka tidak melakukan ritual yang biasa dilakukan masyarakat lokal ketika masuk hutan seperti nyalung ${ }^{13}$,

“Wииии...kami datang tampak muko, pulang tampak punggung" "14.

(kami datang terlihat muka, dan pulang terlihat punggung)

Selain itu, ketika hujan panas terjadi, mereka akan mengambil daun kayu untuk disematkan ke daun kuping mereka. Hujan panas menandakan sang dewi sedang berada di sekitar mereka, dan daun kayu adalah tanda bahwa mereka penduduk lokal, sehingga dewi tidak akan mengganggu dan

\footnotetext{
${ }^{12}$ Disesat rimba merupakan analogi untuk orang yang seringkali tersesat di dalam hutan.

${ }^{13}$ Membunyikan suara nyaring dari mulut.

${ }^{14}$ Bentuk ijin kepada roh leluhur yang berada di hutan agar tidak menyesatkan.
}

menyesatkan mereka di dalam hutan. Syarat lainnya jika mereka ingin buang air kecil di dalam hutan harus dengan jongkok, baik laki-laki maupun perempuan. Aturan itu diberlakukan untuk menghormati dewi hutan. Konstruksi mitos yang dibentuk dengan sangat mistis oleh masyarakat lokal adalah salah satu bentuk perjuangan mereka melawan eksklusi. Yaitu dengan cara mempertahankan sisa sumber daya yang mereka miliki khususnya dari pendatang. Klaim-klaim tentang adat tidak hanya menarik batas identitas dengan etnis lain, tetapi juga menguatkan klaim kepemilikan tanah. Klaim-klaim terhadap akses dan kontrol terhadap tanah juga menguatkan kesadaran teritorial (Darmanto 2012, 273).

\section{Tenggelamnya Pendatang di Danau Lingkat}

Menurut Escobar (2008,112), ada hubungan yang saling berkaitan antara manusia, alam dan Supernatural. Dan akan terjadi transformasi alam ketika mereka ada dalam tekanan pembangunan. Di Danau Lingkat Desa Lempur, yang berbatasan langsung dengan hutan adat, ada penduduk lokal yang merupakan seorang dukun desa. Ia cukup disegani oleh penduduk lokal. Di sisi Danau Lingkat, ia bekerja sebagai distributor batu dari desa. Banyak pendatang dari Bandar Lampung yang bekerja dengannya sebagai kuli batu. Untuk mendapatkan akes mengeksploitasi batu-batu di pinggir sungai, ia tidak butuh melakukan perizinan, karena ia adalah penduduk lokal. Dengan kekuatannya di desa, maka ia dapat mengakses area tersebut.

Dahulu kala, menurut masyarakat desa, Danau Lingkat adalah danau milik desa tetangga. Namun, karena pernah terjadi seorang anak desa itu tenggelam di danau tersebut, nenek moyang mereka melarang penduduk desa setempat untuk bermain di Danau Lingkat menggunakan perahu kayu. Dan hingga kini, Danau Lingkat menjadi hak ulayat Desa Lempur. Dengan syarat bermain air di danau dengan menggunakan rakit dan bukan 
perahu kayu.

Beberapa kali dukun desa ini membuat acara di pinggir danau, dan memungut uang parkir kepada pendatang yang menghadiri acara musik desa tersebut. Namun, tenggelamnya keponakan sang dukun yang berasal dari Medan telah merubah persepsi masyarakat lokal, bahwa dewi hutan telah marah karena diadakan acara di danau yang berbatasan dengan hutan adat tersebut. Keponakan sang dukun dapat dikategorikan sebagai pendatang karena ia tidak lahir di Lempur. Setelah kejadian itu disusul dengan tenggelamnya sepasang kekasih yang sedang bermain rakit di danau Lingkat. Dan mereka juga adalah pendatang dari luar desa. Tenggelamnya pemuda pun terjadi lagi dan itu adalah kuli batu yang bekerja dan tinggal di pinggir danau setiap harinya. Ia sedang pergi memancing menggunakan rakit, dan tenggelam begitu saja.

Banyaknya korban yang tenggelam di Danau Lingkat, membentuk keyakinan pada masyarakat lokal atas bentuk penolakan roh leluhur kepada pendatangyang tidak berniat baik, atau berkata tidak baik di desa itu. Namun, mereka sebagai penduduk lokal pun enggan untuk bermain dan mencari ikan di Danau Lingkat jika tidak benar-benar terpaksa. Tidak seperti dulu ketika orang tua di desa masik anak-anak, banyak yang bukan hanya memancing dengan rakit, mereka juga berani berenang di danau tersebut. Sang dukun bersikeras, bahwa tidak apaapa bermain air di Danau Lingkat, asalkan ditemani oleh penduduk lokal. Roh leluhur malu jika melukai penduduklokal.

Kejadian berturut-turut yang menimpa dukun dan keluarganya tersebut, membawa kepada perasaan bersalah sang dukun karena telah mengganggu tempat roh leluhur hidup, lewat kegiatan mengeksploitasi batu di sisi danau. Dan ia berniat untuk memulangkan semua kuli bangunan tersebut ke Kota Lampung, karena takut dewi hutan mengambil korban lagi seperti yang terjadi di dalam mimpinya.

Selain bentuk Counter exclusion dengan konstruksi mitos oleh masyarakat Desa Lempur, penolakan yang terjadi secara terang-terangan pun sempat terjadi dari masyarakat desa kepada imigran, yaitu imigran dari Palembang yang menurut masyarakat sudah tinggal di desa selama dua bulan terakhir, mencoba untuk membuka lahan di area perkebunan masyarakat desa pada hari Jumat, yang ketika itu masyarakat desa yang mayoritas petani ini libur dan tidak berladang. Selesai shalat jum'at dilaksanakan, masyarakat dihebohkan dengan rapat desa yang digemakan lewat microphone masjid. Bahwa tertangkap pendatang dari Palembang yang mencoba membuka lahan di area perkebunan rakyat, dan dua orang pendatang itu harus di tindak dengan tegas, untuk tidak datang lagi ke Desa Lempur. Dan kasus ini sudah terjadi untuk kedua kalinya, mengusir pendatang yang membuka lahan tanpa ijin dan musyawarah desa dan pemuka adat terlebih dahulu.

Pengusiran ini berbarengan dengan pengusiran LSM Warsi yang ketika itu telah datang untuk melakukan sosialisasi Hutan Kemasyarakatan dalam rangka mempersiapkan masyarakat desa dalam menghadapi program REDD+ yang sedang gencar disosialisasikan di Jambi. Sosialisasi sempat dilangsungkan bersama dengan ketua Dinas Kehutan dan Perkebunan Kerinci, namun anggota masyarakat yang hadir hanya 4 (empat) orang. Tidak sampai sosialisasi itu selesai, salah satu anggota masyarakat meminta LSM tersebut datang lagi lain waktu dengan kesiapan yang cukup. Mereka tidak menerima sosialisasi jika tidak menggunakan power point, tidak dengan tujuan dan maksud yang jelas. Jika hanya ingin membicarakan konservasi, masyarakat desa sudah tidak membutuhkan sosialisasi semacam itu, karena mereka sudah merasa sangat faham mengenai kegiatan konservasi. Selain itu ada bentuk dari kekecewaan yang tampak dari masyarakat desa kepada pemerintah yang seringkali ingkar janji kepada mereka. Ketika TNKS hadir, dan mereka diminta untuk terlibat di dalam perlindungan hutan dari 
kerusakan, mereka seperti mendapatkan angin surga bahwa akan datangnya kompensasi bagi mereka yang sudah berpartisipasi ikut menjaga paru-paru dunia ini. Namun, kenyataannya tidak ada sama sekali kompensasi yang turun kepada mereka, terlebih lagi mereka sudah terusir dari tanah mereka yang berada di dalam area TNKS. Hal tersebut yang lantas membuat banyak dari mereka enggan menghadiri sosialisasi LSM Warsi, karena menganggap hal itu tidak lebih penting dari kegiatannya berkebun di sawah dan ladang.

\section{F. Akses dan Status Kepemilikan Tanah di Desa Lempur}

Masyarakat Desa Lempur merupakan masyarakat matrilineal, yang garis keturunannya berada di garis Ibu. Mereka dapat dikatakan memiliki rantai kekeluargaan yang kuat, sehingga warisan tanah sudah dialokasikan menurut garis keturunannya masing-masing. Lembaga adat dari keseluruhan masyarakat adalah Depati Agung, Depati Suko Barajodan Depati Anomyang jabatan tersebut hanya dapat diisi oleh garis keturunuan Depati yang menjabat sebelumnya. Ketiga Depati tersebut di dampingi oleh beberapa Depati lainnya, dan mereka memiliki ikatan keluarga satu sama lain. Lembaga adat lebih berperan besar dibandingkan dengan Pemerintahan daerah, karena itu kepala desa tidak mempunyai wewenang sebesar para Depati yang berwenang hingga sampai mengatur dimana batasbatas anggota masyarakatnya dalam berladang.

Batas-batas kepemilikan tanah keluarga ini, menjadi alat legitimasi setiap keluarga dalam mengakses sumber daya. Entah tanah itu akan digunakan untuk membangun rumah, kebun atau sawah. Batas tanah warisan dalam garis keturunan keluarga masing-masing tidak dapat digunakan oleh garis keturunan lainnya, dan tentu saja itu berlaku kepada imigran yang sudah menetap di Desa Lempur. Namun sayangnya kepemilikan tanah tersebut tidak diakui dengan surat sertifikasi kepemilikan tanah. Hal ini seperti yang telah dikatakan oleh Li, jutaan warga Indonesia sampai sekarang terus menggarap lahan dan memanfaatkan sumberdaya alam di sekitar mereka berdasar hak adat yang diakui dan dihormati secara lokal, namun tidak terdaftar secara hukum dan tidak diakui oleh lembaga pemerintahan yang bertanggung jawab untuk melakukan alokasi tanah-tanah “negara” (Li 2012, 181).

Mereka secara garis besar sudah mengenal batas-batas tanah yang dimiliki oleh setiap garis keturunan keluarga. Namun, ada batas-batas tanah yang seringkali menimbulkan konflik, yaitu batas tanah perkebunan. Karena kebun masyarakat saling berdampingan, maka mereka harus membatasi tanah masing-masing dengan tumbuhan kayu berdaun merah. Tumbuhan ini ditanam sepanjang garis batas tanah mereka, sehingga cara tersebut mampu meminimalisir keributan. Tanah untukperkebunan menjadi hal yang cukup krusial dibandingkan luasan tanah untuk membangun rumah. Luasnya tanah perkebunan menentukan besaran rupiah yang akan mereka dapatkan di kemudian harinya, sedangkan rumah bukanlah modal atau setidaknya bukan cara untuk menunjukkan prestise seberapa kaya mereka. Rumah-rumah nyaris dibentuk seragam, dibangun dari pohon-pohon kayu yang mereka tebang dari hutan adat, berbentuk rumah panggung atau bertingkat.

Masyarakat Desa Lempur mengakui dirinya terbuka kepada pendatang yang ingin menetap di desa, namun mereka tidak diperkenankan untuk mengakses sumber daya alam di desa tersebut, kecuali mereka bekerja sebagai buruh tani, kuli bangunan, membuka warung, atau berdagang. Selain itu juga mereka hanya menyewa rumah milik masyarakat, hanya segelintir pendatang yang kemudian mendapatkan properti seperti rumah masyarakat yang dijual kepada mereka. Seperti pedagang Baso yang merupakan pendatang dari Jawa. Setelah menetap di desa selama 3 tahun, ia menikahi perempuan dari Desa Lempur, setelah itu ia dapat membeli rumah milik warga desa dan 
menetap di desa tersebut.

Kelompok pemuda desa tidak mempunyai otoritas politik secara adat, tetapi mereka tetap berpartisipasi dalam kegiatan pembangunan desa. Mereka juga tidak segan-segan membelanjakan uang untuk kebutuhan fisik umum yang dibutuhkan oleh masyarakat desa, seperti masjid, gedung pertemuan, dan stadion lapangan bola. Karena hal itu juga berkaitan dengan prestise mereka di mata masyarakat desa yang memiliki jiwa kompetisi tinggi dengan desa lain. Selain itu, pembangunan desa juga merupakan bentuk rasa syukur mereka atas tanah dan SDA yang telah nenek moyang mereka wariskan dari generasi ke generasi. Karena itu di setiap tahunnya mereka mengadakan acara "Kenduri Seko" dengan melibatkan roh nenek moyang dengan ikut menari dan berpesta ketika masa panen telah datang. Dalam kehidupannya, masyarakat desa tidak lepas dari keyakinannya akan roh leluhur yang senantiasa menjaga mereka dari gangguan yang tidak baik untuk keberlangsungan hidup masyarakat desa. Cerita-cerita mitos akan Dewi Hutan dan roh leluhur begitu hidup di dunia mereka, dan membentuk pola perilaku yang khas ketika dihadapkan dengan sebuah fenomena, atau ketika memasuki kawasan yang dianggap menjadi tempat hidup sang leluhur.

\section{G. “Dewi Mendari Kuning” Sebagai Alat Legitimasi Akses Sumber Daya Alam}

Dalam masyarakat Desa Lempur, yang memiliki akses atas pengelolaan SDA di desa adalah penduduk asli desa. Penduduk asli ialah penduduk yang memiliki garis keturunan menurut nenek moyang mereka, yaitu Dewi Mendari Kuning. Konon ia menikahi raja Bagindo Sakti pendatang dari Malaysia yang menetap dan meregenerasikan banyak keturunan di Desa Lempur. Dewi Mendari Kuning ialah dewi hutan, atau mereka katakan sebagai penguasa hutan yang berwujud sebagai makhluk halus, karena itu keberadaannya kekal. Bagindo Sakti yang seorang manusia pergi mening- galkan desa karena bercerai dengan Dewi Mendari Kuning, Dewi kembali ke gunung kunyit membawa anaknya Simamang Tunggal yang juga merupakan makhluk halus. Sehingga keberadaan mereka di dalam hutan diyakini keberadaannya, bahkan sebagian dari masyarakat Desa Lempur yakin, jika mereka mati akan kembali ke gunung.

Seiring berkembangnya masyarakat Desa Lempur, roh leluhur senantiasa menjaga mereka dari gangguan yang datang menyerang masyarakat desa. Sekalipun mereka sedang berada di daerah perantauan, roh leluhur akan tetap menjaga mereka dari orang-orang yang berniat buruk. Dan mereka yang memiliki garis keturunan dengan Dewi Mendari Kuning itulahyang merupakan masyarakat asli Desa Lempur, dan akan menjadi satu kesatuan dengan daerah hutan di sekelilingnya. Begitulah pemahaman masyarakat desa dalam bentuk keyakinannya tentang kelokalan, yang juga diakui oleh imigran yang telah menetap di desa tersebut.

\section{H. Kesimpulan}

Mengerucut pada argumentasi saya di atas, bentuk eksklusi yang terjadi dalam tingkat lokal kepada pendatang, tidak lepas dari semakin menguatnya mitos dewi atas penguasa alam. Dewi yang di reinpretasi oleh masyarakat dari bencana dan kondisi alam sebagai tanda dari kemarahan Dewi, yang kemudian dijadikan alat kontrol masyarakat dalam mengatur kehidupan, di luar aturan adat yang tertulis.

Dari beberapa penjelasan ini dapat ditarik kesimpulan bahwa eksklusi sosial adalah proses pengeluaran atau terputusnya individu dari suatu sistem masyarakat yang tidak mendapatkan pengakuan secara layak oleh masyarakat tersebut dengan beberapa faktor penghambat yang pada akhirnya individu kehilangan kesempatan untuk bersaing memenuhi kebutuhan dirinya sendiri menjadi layaknya masyarakat seperti pada umumnya.

Praktek hutan berbasis masyarakat yang merupakan hutan penyangga dari hutan konservasi 
mengambil dua bentuk utama. Pertama adalah pengakuan kelompok masyarakat, melalui proses legitimasi dan pelembagaan, karena praktek adat yang ada melibatkan tindakan kolektif dalam pengelolaan sumber daya alam. Kedua adalah proses yang lebih politik mengartikulasikan hak-hak atas sumber daya yang ada di bawah ancaman perambahan atau eksploitasi oleh orang luar, apakah orang luar itu adalah dari desa-desa tetangga, kepentingan perusahaan skala besar atau negara yang dipimpin proyek-proyek pembangunan.

Pendekatan hutan kemasyarakatan telah menjadi sebuah kendaraan penting untuk legitimasi keberadaan petani di hutan dan meresmikan hakhak tenurial mereka. Efek eksklusioneryang pertama ini teritorial. Untuk menentukan hak ulayat masyarakat adat biasanya dimulai dengan pemetaan wilayah yang diklaim oleh "masyarakat" yang dimaksud, sebuah proses yang sering melibatkan menggambar garis-garis tegas, pemasangan patok dan di mana hak-hak teritorial tidak kaku ditentukan. Eksklusi kedua adalah sosial, ketika "masyarakat lokal" didefinisikan dengan cara yang membuat para migran atau minoritas mungkin menemukan bahwa hak-hak de facto mereka ada dalam pengawasan dan terpinggirkan atau bahkan ditolak mentah-mentah.

Bentuk perlawanan masyarakat lokal terhadap proses eksklusi yang mereka alami ketika TNKS hadir di tengah-tengah mereka ialah dengan mempertahankan kepemilikan SDA yang mereka miliki dan diakui secara hukum. Dimana hutan Adat adalah hutan milik masyarakat yang kegunaannya sebagai sumber air, dan dapat ditebang jika digunakan untuk kebutuhan masyarakat desa. Wilayah ulayat yang dilegitimasi sebagai milik masyarakat desa pun mereka proteksi dari gangguan luar. Seperti merekonstruksi mitos-mitosyang digunakan sebagai alat penolakan kepada pendatang yang akan mengeksploitasi alam mereka. Hal ini kemudian mampu meyakini orang luar desa atas kesaktian alam mereka, juga diyakini oleh masyarakat desa itu sendiri sebagai kontrol yang digunakan masyarakat kepada diri mereka sendiri.

\section{Daftar Pustaka}

Anonim. 1993, Menuju pengelolaan daerah interaksi taman nasional kerinci seblat, Badan Perencanaan Pembangunan Daerah Tingkat II Kabupaten Kerinci, Kerinci.

Ben White, Saturnino M. Borras Jr., Ruth Hall, Ian Scoones \& Wendy Wolford 2012, "The new enclosures: critical perspectives on corporate land deals", Journal of Peasant studies, 39:3-4, hlm 619-647.

Darmanto 2012, Berebut hutan siberut : orang mentawai, kekuasaan, dan politik ekologi, Gramedia, Jakarta.

Escobar, Arturo 2008, Territories of difference, place, movements, life, redes, Duke University Press, London.

Hall, D., Hirsch, S. dan Li 2011, The powers of exclusion: land dilemmas in southeast asia, NUS Press, Singapore.

$\mathrm{Li}$, Tania M 2012, The will to improve : perencanaan, kekuasaan, dan pembangunan di indonesia, Marjin Kiri, Jakarta Pusat.

Luthfi, Ahmad, N 2013, "Review buku : eksklusi dan inklusi sebuah sisi mata uang”, Bhumi Jurnal Ilmiah Pertanahan PPPM - STPN. No. 37 tahun 12, STPN : Yogyakarta.

Murtijo, Nugraha, A 2005, Antropologi Kehutanan, Wana Aksara, Banten.

Ribot, J.C. dan Peluso, N 2003, "A theory of access", Rural Sociology.

Scott, James C 200o, Senjatanya orang-orang yang kalah, Yayasan Obor Indonesia, Jakarta.

Wartaputra, Sutisna 1990, Pola pengelolaan daerah penyangga (suatu acuan pemikiran), Direktur Jenderal PHPA Departemen Kehutanan, Jayapura.

\section{Sumber Internet:}

http://jambi.tribunnews.com/2013/o2/13/longsorgeothermal-di-kerinci-murni-bencana-alam http://regional.kompas.com/read/2013/o2/o7/ 02361286/7.Juta.Hektar.APL.Tak.Terlindung 